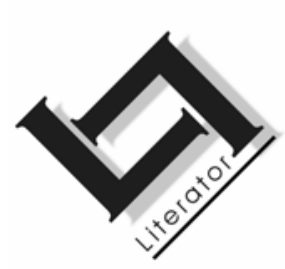

\title{
Fay Weldon, liberal feminism and the praxis of Praxis
}

\author{
Andrew Foley \\ Department of English \\ Wits School of Education \\ University of the Witwatersrand \\ JOHANNESBURG \\ E-mail: Andrew.Foley@wits.ac.za
}

\begin{abstract}
Fay Weldon, liberal feminism and the praxis of Praxis

This article focuses on Fay Weldon's novel, "Praxis", as a means of exploring the concept of "liberal feminism". "Praxis" charts the development of the eponymous main protagonist from a woman complicit in her own patriarchal oppression to a radical feminist activist and finally to the point where she comes to a liberal realisation of the nuances of individual women's experiences and the complexity of emancipation. The novel may be regarded as a liberal feminist text in its emphasis on both gender equality and individual liberty, and in its insistence that society may be positively reformed within the paradigm of the liberal state and without resorting to radical extremism. Published in 1978, the novel anticipates the later shift in feminist thinking from an exclusive concern with women's rights to a more inclusive liberal vision of human rights.
\end{abstract}

\section{Opsomming}

\section{Fay Weldon, liberale feminisme en die voorbeeld van Praxis}

Hierdie artikel ondersoek Fay Weldon se roman, "Praxis", as 'n voorbeeld van "liberale feminisme". "Praxis" beskryf die ontwikkeling van die hoofkarakter van 'n vrou aandadig aan haar eie patriargale onderdrukking tot 'n radikale feminis en uiteindelik tot by ' $n$ liberale besef van die nuanse van individuele vroulike ervarings en die ingewikkeldheid van emansipasie. Die roman kan as 'n liberale feministiese teks beskou word deur sy klem op geslagsgelykheid sowel as individuele vryheid, en weens sy aandrang dat die samelewing positief verbeter kan word binne 
die paradigma van die liberale staat sonder om ekstremistiese maatreëls te tref. Die roman is in 1978 gepubliseer, en antisipeer derhalwe die latere skuif in feminisme van 'n eksklusiewe bemoeienis met vroueregte tot 'n meer inklusiewe liberale visie van menseregte.

\section{Introduction}

To apply the term liberal feminist to a writer as idiosyncratic and even transgressive as Fay Weldon may at first seem surprising. Although she is certainly a feminist in the sense that her writing is, as she puts it, "preoccupied with women's state in the world" (Kenyon, 1988:112), many of the views which she expresses in her novels, together with her ironic vision of general societal entropy, may not appear compatible with mainstream liberal feminism. And yet, beneath the superficial chaos of the world which she portrays so effectively in her fiction, there emerges a perspective which is deeply compassionate, sympathetic and humane. As she herself has noted (Lowry, 1982:25), all her work is founded upon "a discussion of ethics - that's the only thing that makes a play or a book interesting, and indeed justifies the great number of books in the world". More especially, as this article will argue, the ethical feminism which her writing evinces is one which is vitally informed by the central values of liberalism: the moral primacy of the individual and her/his liberty and autonomy; gender equality; and the belief that contemporary society can be ameliorated without resort to impractical extremism. These issues will be explored through a careful reading of one of Weldon's most important novels, Praxis. Published in 1978, the novel certainly presents an explicit and detailed critique of modern patriarchy, but it moves beyond that to problematise a number of feminist issues and to question the direction which certain strands of the radicalised second-wave feminism of the 1960s and 1970s were beginning to take. In particular, the novel's ending anticipates the later drift in feminist thinking from an oppositional concern with exclusive women's rights towards a more inclusive vision of human rights. As such, it serves to prefigure what more recent feminist scholars like Virginia Sapiro (1992:1) have termed the "revindication" of liberal feminism which developed in the 1980s and after. 1

1 Sapiro's focus is specifically on the work of Mary Wollstonecraft, whose recuperation as a seminal and subtle feminist thinker has signalled the positive revaluation of liberal feminism generally. For more wide-ranging accounts of these trends in feminist theory, see Karen Green (1995), Rosalind Coward 


\section{Background}

As Alex Clark observes (2002:1), just read Fay Weldon's autobiography, the wittily and aptly titled, Auto da Fay (2002), "and her fiction suddenly seems a whole lot less peculiar". Weldon has at times been criticised for making her characters' lives rather too eventful and strange than is plausible, and yet it is apparent that much of their experience has been drawn from Weldon's own eventful and strange life. Born in England in 1936, she was raised and schooled in New Zealand in the company entirely of women, her philandering father having deserted the family shortly after her birth. The impoverished family eventually returned to London, and Weldon won a scholarship to St. Andrew's University, where she graduated with a Masters degree in Economics and Psychology. As an unmarried mother in the conservative 1950s, however, she found it difficult to find work and she went through what she describes as a number of "odd jobs and hard times", including a decidedly odd, sexless marriage of convenience to a man twenty years her senior, who derived pleasure from pimping her out to a Soho nightclub. She did achieve success as an advertising copywriter, however, coining the famous slogan, "go to work on an egg" (though she characteristically claims that she would have preferred to be remembered for the rejected catchphrase, "vodka gets you drunker quicker"). She became a full-time writer only in the late 1960s, but has since demonstrated a remarkably prolificacy, producing over twenty novels and collections of short stories, as well as dozens of radio and television plays and adaptations. She went on to marry Ray Weldon, with whom she had three further sons, and is currently married to the poet, Nick Fox. Thus, like the eponymous protagonist of Praxis, Franklin Fay Birkinshaw Davies Bateman Weldon Fox has taken on and lived through a succession of self-identities, becoming in the process not only a successful writer of fiction, but also a well-known social critic whose sometimes controversial views have not prevented her from recently being awarded a CBE. 2

(1999), and Ruth Robbins (2000). Attention is also directed to the work of such liberal feminist writers as Susan Moller Okin (1989), Onora O'Neill (2000), Marilyn Friedman (2003) and Martha Nussbaum (2006).

2 Most recently, Weldon has espoused some rather conservative Christian views in non-fictional works like What makes women happy (2006), for example (and see her interview with Stuart Jeffries, 2006), though her fiction continues to display a characteristically ironic perspective, as in her most recent novel, The spa decameron (2007). 
Weldon has also frequently courted controversy in the subject matter of her fiction. The life and loves of a she-devil (1982), for instance, takes the form of a darkly disturbing fable about a woman, Ruth Patchett, who takes revenge on her cheating husband by literally transforming herself into his pretty, petite mistress. Big women (1997) is an acidly satirical account of the hypocrisy and deceit involved in the founding and development of the iconic feminist publishing house, Virago. And The Bulgari connection (2001) has been described as nothing less than a shameless, subsidised advertisement in novel form for the Bulgari jewellery company. She has been accused, not altogether unfairly at times, of writing too much too quickly, rather in the manner of a copywriter, so that some of her work does suffer from a sense of repetitiveness, of somewhat perfunctory characterisation, and of underdeveloped narrative structure. In her best work, however, of which Praxis is perhaps the finest example, her pointed and economical style is well suited to her depiction of the heroine's struggle to adapt to a confusing and rapidly changing social landscape. If Praxis' experiences appear overly multifarious, it is because the novel seeks ambitiously to present, as Marilyn French puts it, "the history of womankind condensed to its essentials", to compress "in the account of the life of one woman an entire spectrum of women's lives" (1978). ${ }^{3}$ It is to an account of the extraordinary life experiences of this extraordinary character that this article now turns.

\section{Praxis}

When Fay Weldon first came to prominence as a novelist, she was hailed as "the voice of rising feminist consciousness in the United Kingdom" (see Rubenstein, 2005:54). Her early novels, which include The fat woman's joke (1967), Down among the women (1971), and Female friends (1974), continue to be regarded by some critics as work which "perhaps best catches the mood of second-wave feminism" (Head, 2002:96). Importantly, however, as Weldon has pointed out (Kumar, 1995:16), it was not simply a case of her being influenced by the women's movement, but rather of a more dynamic and even symbiotic relationship:

I like to think I influenced it! I started writing in England at the same time as the women's movement there got going, so we

3 Short-listed for the 1979 Booker Prize, it was deemed by one of the judges, the novelist A.S. Byatt (1979:10), to be, apart from Doris Lessing's The golden notebook, "the single best modern novel about the condition of women". 
were more or less contemporary phenomena. The writer and the movement [began] to feed into each other.

In reading a novel like Praxis, it is important to take cognisance of the fact that Weldon's work has never been merely a reflection of the prior concerns of the movement, but that she has always maintained a degree of artistic independence and critical objectivity, challenging and at times subverting simplistic or glib notions of feminism. She has, for instance, consistently resisted superficial assumptions about sisterhood, where individual distinctions are flattened into conformity with a group identity, as well as a radicalised oppositionality in which thoughtful debate is replaced by militant but intellectually shallow rhetoric. By contrast, Weldon has sought to explore the particular nuances of individual women's experiences and to acknowledge the complexity of female emancipation. In particular, it is this concern with balancing the ideals both of gender equality and of individual liberty which gives Weldon's feminism its characteristically liberal quality. Such liberal feminism is thus to be distinguished from conservatism, on the one hand, in its insistence on the equal moral worth of all persons irrespective of gender, and from radical thought, on the other hand, in its assertion of the primacy of the individual against the claims of any social collective. It also differs from certain forms of sceptical, anti-liberal postmodernism in that it maintains a belief in the possibility of positive social reform within the paradigm of the liberal state.

Although Weldon's work frequently calls into question certain aspects of feminist thought, it is nevertheless true that for the most part Praxis functions as a "devastating indictment of patriarchal power and male supremacy" (Palmer, 1990:60). It forms part of a general political mobilisation in which, as Weldon (1998:viii) has observed elsewhere, one could sense "the forces of praxis converging", but for "the gender revolution", not "the Communist one". 4 The novel charts Praxis Duveen's gradually burgeoning awareness of the subservient position of women generally in a male-dominated society, and of her particular oppression at the hands of a succession of male partners. Like several of her novels, the story is told in chapters alternating between third-person and first-person narrative: 5 the third-person

4 Despite the novel's title, Praxis is, like all of Weldon's work, manifestly not Marxist in orientation.

$5 \quad$ Randall Stevenson (1993:107-108) offers a lucid account of this technique in Weldon's Down among the women (1971), for instance. 
narrator objectively recounts the events of Praxis' life from her early childhood in the 1930s through to the current day (that is, the late 1970s), while the first-person narrator, the older and wiser Praxis of the present moment, is able to reflect back and comment subjectively on the significance of the life she has led and the changes which both she and her society have undergone over the years. In a crucial sense, then, Praxis' personal development figures as a representation of the evolution of feminist thought over the timespan of the novel, and registers the progressively changing attitudes in the popular consciousness. More specifically, the older Praxis is able to claim with some justification that she "helped to change the world" and "made life what it is" for the more liberated and assertive young women of contemporary times (p. 17). 6 There is thus a certain didactic element in Praxis' account of her experiences: "Watch Praxis. Watch her carefully. Look, listen, learn" (p. 120). That it is to be by no means an obvious or simplistic lesson, however, is signalled early in the novel by the multiple and unusual meanings suggested for Praxis' name: 'turning-point, culmination, action; orgasm; some said the Goddess herself " (p. 11). These terms clearly require some explication, and, as Weldon (Kenyon, 1988:114) has remarked, part of the aim of the novel is "the fictionalised workingout of all these meanings".

\subsection{Relationships}

Praxis grows up in Brighton in the years before the Second World War in a culture characterised not only by female subservience but also by intense sexual repression and narrow-mindedness, "a time when women's instincts were so much at variance with the rules of society" (p. 43). It is also a time when the majority of women were socialised into becoming complicit in their own oppression. As Praxis later wonders about her already unstable mother, Lucy:

Was she always mad, or did the world send her mad with its prudery, hypocrisy and unkindness? Or was it the likes of her that made society what it was, prudish, hypocritical and unkind? (p. 59.)

Deserted by her husband in the First World War, Lucy has endured the secret shame of "living in sin" (p. 10) with the dissolute Benjamin Duveen, the father of her two illegitimate daughters, Hypatia and

6 All page references are to the Sceptre edition (1978) of the novel and will be cited by means of page numbers only. 
Praxis. After he too abandons her, when Hypatia is seven and Praxis just five years old, Lucy ekes out a precarious living for a decade, until it all becomes too much for her and she is institutionalised. If Praxis' family upbringing is more than a little bizarre, her schooling is not much better. She is taught early on that women "were the daughters of Eve and responsible for leading men into sin and for the loss of Paradise, and must make amends for ever" (p. 22); an innocent crush on an older schoolgirl is labelled "filthy" and "perverted" (p. 54); and there is absolutely no contact with boys whatsoever. It is little wonder that she "found it difficult to believe in the reality of the world, so oddly was it arranged" (p. 49).

Having more or less survived her childhood, Praxis is soon confronted as a young woman by the reality of a patriarchal society in a variety of forms, both overt and subtle, as her life's path takes her through a series of psychologically abusive and damaging relationships. Through them she learns that in her culture patriarchy has been comprehensively internalised as an almost religious principle:

We predicate some natural law of male dominance and female subservience and call that God. Then what we feel is the pain of the female Lucifer, tumbling down from heaven, having dared to defy the male deity. (p. 16.)

In this, she echoes, though in rather more poetic terms, the central point which the great liberal thinker of the nineteenth century, John Stuart Mill, made in his essay The subjection of women (1869:40):7

... unnatural generally only means uncustomary, and ... everything that is usual appears natural. The subjection of women to men being a universal custom, any departure from it quite naturally appears unnatural.

In the face of this subjection, the overwhelming feeling which she and her female friends experience is that of frustration and hopelessness:

A sense of desperation seemed to afflict them: as if whatever path they took, whatever new avenue opened up, it would narrow and block, and they would be turned round once again, to face their own natures. (p. 117.)

$7 \quad$ Much of Mill's work, and this essay in particular, were heavily influenced by Harriet Taylor, with whom he shared a most unorthodox partnership over the course of more than forty years. 
The first relationship to, and in which she finds herself "subjected" is with Willy, a fellow student, in the years just after the Second World War, at Reading University, where they are both studying political science. Tellingly, Praxis was only accepted for this traditionally "men's option" because her "odd name" had led the university to believe that she "was a man" (p. 99). 8 Praxis is not particularly attracted to Willy, preferring instead his friend, Phillip, but she settles on Willy "for the status of having a steady boyfriend" (p. 111). From the outset, however, Willy imposes his "natural" male dominance, privileging his own interests over hers in every aspect of their lives. For her part, Praxis, whose sexual naïveté is matched only by her lack of social awareness, is initially happy to allow him to do so: she types his essays before even starting her own; she ensures that she earns lower marks than he does; and she eventually leaves university before taking her degree to become installed as his commonlaw housewife back in Brighton. Once living together, he turns her into his domestic drudge, looking after both him and their unofficially adopted daughter, while carefully maintaining total control over their finances in order to guarantee her dependence on him. Clearly, she should have taken heed when she first met him that his beard "gave him an almost patriarchal air" (p. 104).

She does eventually manage, after a number of years, to extricate herself from this "wretched" existence (p. 139), only to tumble almost immediately into another one, for within a few months she is pregnant and married to Yvor, "this advertisement for a clean-cut decent man" (p. 189). If Willy had consistently sought to undermine her for being "too nearly his equal" (p. 170), then, Yvor, in a different though equally deleterious way, also tries to make her something he wants her to be - "an angel come down from heaven" (p. 190) - rather than accepting her for who she is. And again, she allows herself to be artificially constructed according to the desire of the male:

He did not want to hear Praxis' life story, or Praxis' principles. He wanted her life to have begun the day he met her, and his opinions to be hers. She could see it might be restful. It was how most women lived. (p. 191.)

8 This mirrors Weldon's own experience of being accepted for a similar course at St. Andrew's University because her given name, Franklin (which her mother charmingly believed was a feminine form of Frank), had caused the university to assume she was male. 
Within a short space of time, she finds herself imprisoned in the stultifying bourgeois domesticity of a typical 1950s lifestyle, living on a housing-estate where all the homes and children look the same, where people care only about superficial appearances and material possessions, and where she, like the other wives, is transformed into little more than a living ornament: "blonde curls; doll's eyes; doll's mind" (p. 200). In this numbing suburban milieu, only dimly does she feel that her husband "blocked her vision; that there was something else to be seen if only he would get out of her way" (p. 193). Praxis is, fortuitously if painfully, rescued from this "half life" (p. 201) by her husband's discovery of her past and his shocked recognition at last of her "reality" (p. 201) as a person. With their relationship irreparably damaged, Praxis finds the motivation to escape this "limbo" (p. 196), and to pursue whatever it might be that she needs as a woman to make her life "more her own" (p. 204).

Praxis's journey to independence and self-actualisation takes another strange turn, however. Having abandoned her own husband, children and home, she contrives to steal the husband, children and home of Irma, her old university friend. Irma has married Phillip, Willy's former flatmate, who is a film director, and who, unlike Yvor, is rather charmed by Praxis' colourful past: in any event, in what is now the swinging sixties in London, a great deal of the sexual guilt and shame of the past has faded. Like Yvor, however, Phillip too is incapable of seeing Praxis for who she really is, tending instead to sublimate reality through a lens: as he admits, "I can only face real life if there's a camera between it and me" (p. 236). And soon,

Praxis had the feeling that her life had lapsed out of colour and into black and white: as if she too were now some part of Phillip's imagination. What she saw lacked solidity: as if Phillip were making an eternal square with his two hands and framing her through them; able at will to cut to the next square, to edit and delete. (p. 222.)

Sure enough, Praxis eventually finds herself edited and deleted from Phillip's life, for just as he deserted Irma for Praxis, so he deserts Praxis for Serena, one of his starlets, and Praxis, now almost forty, is alone.

As is characteristic of much of Weldon's fiction, however, the issues are neither simple nor clear cut, at least not from a straightforward feminist viewpoint. In the first place, though it is certainly true that none of Praxis' partners fulfils her or treats her as well as he might have, a certain degree of sympathy is nevertheless afforded to 
them. Like Praxis herself, for instance, each of these men has been psychologically scarred by hurtful relationships with parents who are neglectful, uncaring, or simply absent. Both Willy and Phillip, moreover, served as young soldiers during World War II and suffered emotional trauma through their exposure to so much death and destruction (p. 100-101). As with so many men of their time, they have to learn, like the generation of World War I veterans before them, that human beings

... added up to more than the tattered shards of flesh hanging on the barbed wire of the Ypres front; the grinning faces, skin stretched over bone ... The world was something more than a charnel house, a human factory farm, insanely breeding flesh out of flesh as its way of cheating death (p. 22-23).

In the second place, as Praxis comes to acknowledge, it "does not take a man to make a woman cry" (p. 242); it is often the case that women themselves are to blame for selfishly causing pain and suffering for other women:

We betray each other. We manipulate through sex: we fight each other for possession of the male ... We prefer the company of men to women. We will quite deliberately make our sisters jealous and wretched ... And all in the pursuit of our selfesteem, and so as not to end up cold and alone (p. 241-242).

And in the third place, Praxis is forced to concede that in many cases women must take responsibility for allowing themselves to be dominated and exploited by men. Looking back over the losses in her life, she has to accept at least partly "that my own actions and my own obtuseness had brought these losses about" (p. 175), and that she should not have so meekly "assumed, along with everyone else, that a man's convenience rated more in the great scheme of things than a woman's pain" (p. 175). Thus, when she complains to Irma about her domestic misery, she is bluntly told, "Nobody made you do it, you volunteered" (p. 265). And she finally reaches the point where she can admit to herself that she ought not to "blame" her partners in a simplistic sense, because "she knew that she had done it to herself" (p. 199).

\subsection{Marriage, children and the domestic sphere}

Weldon's point, then, is that the underlying cause of so much unhappiness in relationships cannot be reduced merely to the fact of patriarchal supremacy. Certainly by the time Praxis' second marriage is ending, it is the 1970s and many of the worst aspects of 
patriarchy in marital partnerships had been, or were in the process of being, eroded in the wake of the sexual revolution.9 Instead, hearing her husband crying in bed one night, she recognises that it is both men and women who are frequently made miserable by being in relationships: "I seem to have heard that for so long, she thought, from so many people. Women in relation to men: men to women. There must be something wrong" (p. 208). What is wrong, Weldon implies through Praxis, is not so much gender inequality as such, but the very institution of the traditional family structure itself. In one of several distinctively transgressive moves in the novel, Weldon calls into question the very principle of monogamous marriage and parental obligation, and not just the conventional role of women within the nuclear family unit. Weldon's argument, as borne out in the experiences of Praxis, but also through the words and deeds of many characters in the novel, is that the customary notion of family is simply not appropriate for every individual woman, and that women are entitled to decide for themselves what lifestyle is most likely to bring them happiness. To be sure, as Praxis observes, some women can find contentment in stable, monogamous marriages: "I have friends who married as virgins and only made love with their husbands all their lives, and wouldn't want it any other way" (p. 43). Similarly, there are women who believe resolutely "that to be a wife and mother is the highest purpose of a woman" (p. 266). At the opposite extreme, however, other women seek fulfilment through the total rejection of such traditional roles. Praxis' stepdaughter, Victoria, for instance, discovers happiness as a lesbian, assuring her family "that lesbianism was a higher state than heterosexuality: that there was affection, comfort, consolation to be found in girls; and only war with boys" (p. 256). In like vein, the "Women's Libbers" (p. 248), as Praxis initially dubs Bess, Raya and Tracey, take the step of beginning a separatist women's commune in Wales, without feeling the need for men at all (p. 291). Still others, like Praxis herself, though not rejecting male society and though still seeking heterosexual relations, nevertheless find enduring monogamy impossible: as she confesses, "I seem to have difficulty ... in actually loving a man in any permanent sense" (p. 277).10

9 For an detailed account of the legislative changes which took place at this time in the United Kingdom, see Rowbotham (1997:401-413).

10 In this regard, Luce Irigaray's thinking in This sex which is not one (1977), is of particular interest. Generally, however, and despite the efforts of those like Toril Moi (1985) to popularise it, the work of French feminists such as Cixous, Iriga- 
Even more radically perhaps, Praxis comes to question the obligatory "social responsibility" (p. 239) for women to have to look after their children. To the continuing charge that it is "an unnatural crime" (p. 209) to leave one's own children, Praxis cites the example of the Alaskan brown bear who after a time simply abandons her brood to look after themselves. To be freed of this obligatory role, Weldon implies, would be to free women of "the anxiety that plagues the maternal life", that "gnaws away at the foundations of female experience", and that "keeps women's heads bowed" (p. 143-144). And indeed, in the novel, parenting is revealed to be a matter of choice rather than compulsion: Willy's new girlfriend Carla takes responsibility for Praxis' adopted daughter, Mary; Yvor's second wife, Diana, brings up Praxis' own children, Robert and Claire; Praxis, for her part, raises Irma's children, Victoria and Jason. Moreover, all three men, Willy, Yvor and Phillip, find themselves having to take a more equitable share of the parenting load, and end up both being good at it and enjoying it. And so, despite the apparent confusion of all this, the children do "well enough" (p. 143). Weldon is not suggesting, of course, that children do not need good parenting in the form of love, protection, understanding and acknowledgement (p. 210), but simply that "blood ties don't matter" (p. 261) in and of themselves, and that mothers should not feel in contemporary society that they are obliged to remain within the conventional family unit for the sake of their children.

Such views may seem relatively uncontroversial by today's more relaxed standards, but in 1978 Weldon was making a contentious point. The more conventional view is expressed by one of the nurses at Lucy's mental hospital: "That's the trouble, these days. There's a great deal of vagueness in family relationships, and far too much loose living" (p. 181).11 Weldon's suggestion that women ought to be free to pursue happiness in any variety of roles outside of the traditional family structure was controversial because it seemed to call into question one of the foundations of the original liberal State. The nuclear family, as it is understood today, emerged

ray and Kristeva seems to have limited bearing on the actual political and legislative struggles of feminist activism (see Todd, 1991:51-68).

11 This view was echoed by the conservative critic, Harry Blamires (1983:295), who saw Weldon's work on at least one level as espousing "femininity rampant and combative", which must lead to "promiscuity, careerism and disaffection ... yet no moral is drawn". Weldon herself (in Kenyon, 1988:117) recalls that after her early publications, including Praxis, "some people would leave the room in disgust when I entered". 
after all as an expression of the liberty of the individual to construct a vision of the good life within a private space of autonomy, safe from interference by the social collective, whether in the form of direct coercion or public opprobrium. The notion of the privately owned home as one's "castle" suggests that the individual's freedom did indeed once need such protection. For Weldon to claim that there is something "wrong" (p. 208) with the nuclear family structure, is in effect to argue that cultural norms have changed radically (at least in the advanced liberal democracies of the West) and that a new, more flexible conception of societal institutions is needed. In fact, similar arguments were being made at the time by a number of liberal social philosophers. Most notably, Robert Nozick, in his seminal work, Anarchy, state and utopia, published in 1974, maintained that people needed to be afforded the freedom to work out the social arrangements which best enabled them to pursue their personal vision of the good life. However, because contemporary citizens now have so many new and different ideas about what constitutes the good life, it is necessary for the State to become much more malleable than in the past. The modern State, Nozick argues, needs to become an increasingly minimalist one, whose primary function is not to regulate its members into conformity, but rather to provide merely an overarching, neutral "framework" within which different visions of "utopia" may be actualised.12 As Nozick (1974:311-312) puts it:

There will not be one kind of community existing and one kind of life led in utopia. Utopia will consist of utopias, of many different and divergent communities in which people lead different kinds of lives under different institutions ... Utopia is a framework for utopias, a place where people are at liberty to join together voluntarily to pursue and attempt to realize their own vision of the good life in the ideal community but where no one can impose his own utopian vision upon others ... Half of the truth I wish to put forth is that utopia is meta-utopia: the environment within which utopian experiments may be tried out; the environment in which people are free to do their own thing; the environment which must, to a great extent, be realized first if more particular utopian visions are to realized stably.

It is not clear whether Weldon was familiar with Nozick's work when she wrote Praxis, but there certainly seems to have been an in-

12 It should be noted that certain radical feminists, such as Iris Marion Young (1990), deny the possibility of such neutrality and call for the entire dismantling of the liberal state. 
fluence of ideas, reflected not only in Weldon's vision of women exploring a multitude of new and different roles, but also in the very language of the text itself. Early on in the novel, for instance, the older Praxis admires the younger generation of New Women for their "freedom ... dignity ... pride" (p. 41), and feels justifiably proud for having played her part in helping to broaden the life opportunities which they now enjoy, even as she feels that concerted efforts by women must continue to entrench and expand these new found freedoms: "We can't stick to our principles, act as we ought, fight for our causes, not non-stop, all our lives. We must be prepared to take shifts in our fight for utopia" (p. 41). Later on, Praxis, considering her options outside of marriage, senses that women may in fact be better suited to a new, flexible social environment than men, since they have always had to adapt to new circumstances in the course of their lives:

There were so many different worlds, it seemed to Praxis, with very little cross reference from one to the other: each with its different ways and standards, its different framework of normality. Women crossed the barriers easily: were required to by marriage, moving house, changing status: men seldom crossed them, went on as they began ... (p. 202).

The destabilising of the compulsory traditional family structure, then, far from undermining one of the bases of the democratic State, actually represents a further step in the evolution of liberal society, one in which the life choices available to people, and to women in particular, are greatly and inspiringly expanded.

Nevertheless, there do remain a number of obstacles in the way of a truly degendered society, and one of the more intractable of these lies in the fundamental dilemma of balancing home and work, the domestic and the economic, of succeeding both as a home-maker and as a career-woman. Praxis' sister, Hypatia, goes to the extreme of forgoing a family life altogether in the pursuit of her career. Significantly, she is named after "a learned woman" of ancient Greece, who was "stoned to death by an irate crowd for teaching mathematics when she should have stayed modestly at home" (p. 11). Hypatia in the novel is not literally stoned, and even succeeds in earning an $\mathrm{OBE}$, but she is forced to sacrifice her femininity in the endeavour. As she concedes, "I could never have got married ... I couldn't have coped with that and a career" (p. 271), and part of the key to her success in the business world is precisely because, as she observes, "I'm not like a woman .... They forget I'm a woman" (p. 251). For Praxis, such a way of life represents an unacceptable 
incompletion, since her sister "could be as much a success in the world as she liked, but [she] was a failure as a woman" (p. 247). At the other extreme, Praxis' adopted daughter, Mary, qualifies as a doctor only to give everything up to devote herself to being a fulltime wife and mother, prompting Praxis to warn her desperately but to no avail that she'll "shrivel up and die, mentally and emotionally. Women do." (p. 258.)

For a while, Praxis does try to seek fulfilment in both the economic and the domestic spheres, caring for her family while carving out a career in advertising. As "a working mother" (p. 239), she seems on the surface to be "happy" and "lucky", but most of the time she just feels "tired" (p. 246). She represents another example of what Olga Kenyon (1988:105) has termed Weldon's supposedly "emancipated mothers" who are "exhausted by the double burden of home and work", or what Margaret Drabble (Kenyon, 1989:49) has described as the illusory liberation of many women of the 1960s and 1970s, whose "freedom was a mockery because we were all overloaded, exhausted". She encounters other problems of a particularly sexist nature at work as well: her name is routinely omitted from the credits even though she has done all the copywriting; her ideas for more enlightened advertising are brushed aside; and she is compelled to produce copy which is essentially degrading to women, a typical example being, "God made her a woman, love made her a mother with a little help from electricity!" (p. 230.)

The question which Weldon raises, then, is how it is possible in a free-market economic system for women to achieve happiness and success as working mothers, not simply doing the "boring, repetitive, tedious jobs" (p. 260) usually assigned to women, but actively competing on an equal footing in the open market-place. In exploring this question, Weldon articulated what has become, and continues to be, a crucial concern of liberal feminist theory. Karen Green (1995:97) puts the argument lucidly:

It is often assumed that the political programme which can be justified on the basis of liberal feminism is exhausted once women have the vote and there is genuine equality of opportunity. But while women continue to contribute more than men to the maintenance of the family, and do unpaid work within the private sphere, equality of opportunity is unlikely to lead to anything like equality of outcomes. If there is competition for positions of power and prestige, those who are free of the demands of childcare will, all other things being equal, be in a better position to succeed, and, as is now the case, the vast majority 
of these positions will be held by men whose wives are prepared to carry the main burden of childcare, or by childless women or men.

Although Weldon does not in the novel propose any programmatic solutions to this dilemma, the very fact that she raises it in so forceful a manner, both in Praxis and several other of her novels, has served to contribute valuably to a debate that is far from resolution, and which must be taken forward in order, as Green $(1995: 98)$ puts it, "to accomplish liberal feminist aspirations".13

\subsection{Transgression}

The debates and dilemmas which Weldon explores in Praxis are in many ways drawn from the typical experiences of ordinary women of the time, as they sought to free themselves from the oppressive structures of patriarchal power. At another level, however, the narative stretches the limits of fictional realism to include a number of strange and troubling episodes which expand, disturb and even challenge the conventional feminist position which the text generally advances. Lorna Sage (1992:113) has described her style at this level of narrative as "matriarchal realism", in which there is "a substitution of key symbolic episodes for the continuities of a patriarchal bourgeois realism". While this is generally true, Sage's rather portentous terminology needs to be tempered by an acknowledgement of Weldon's pervasive mixture of comedy and the bizarre in her writing, and thus of the subversive potential of what she calls "frivolous fiction" (Barreca, 1994:3). At any rate, in a number of these symbolic episodes, Praxis' actions transgress even the most flexible standards of female behaviour, and serve to complicate, but also deepen, the novel's moral vision.

In the first of these transgressive episodes, Praxis, in desperately seeking an escape from Willy's emotional and financial control over her, takes the advice of her friend, Irma, that "the only way out ... is to sleep your way out" (p. 142). And so, to earn money, she and her equally frustrated friend, Elaine, whose domineering father had forbidden her to go to university and who now keeps her working in

13 Although there is no scope within the present article to explore them, Green proposes a number of potential solutions, including ways of providing men with the incentive to contribute more to domestic labour; detailed compensation for maternal duties; and mechanisms for guaranteeing a 50\% female participation in parliament to ensure that women's best interests are secured. 
his grocery shop, turn to prostitution at a Brighton bar resonantly named "Raffles Esplanade Dive". Far from feeling brutalised and exploited, however, Praxis finds the experience both liberating and educative. It is, as she observes, better than working at some dull and menial job:

I was earning, after all ... I was gaining some agreeable physical sensations, and stretching my vision of humanity; I was free to pick and choose my clients, and had time left over to look after home and child. Why was I so easily made to feel it was distasteful, when my own experience indicated that it was not? (p. 176.)

She soon has enough money saved to leave Willy, but her decision is prompted not by financial independence, but by a further "extraordinary happening" (p. 150), which still further violates accepted social mores. She takes on a new, rather elderly, yet elegant client, to whom she immediately feels a strangely affectionate connection. Only after having had sex with him does she realise that it is her own father, who had abandoned the family when Praxis was still a small child. Though initially feeling stunned, she knowingly consents to sex a second time, rationalising that "incest ... was merely another label; so, come to that, was father ... and he had renounced his rights to that a long time ago" (p. 154-155). She even achieves orgasm, "with bitterness and exultation mixed", evoking in him a response of "reverence" (p. 155). At a darkly symbolic level, this taboo act functions as a psychological and even mythological overturning of patriarchy, as "she had altogether demystified him: turned him from saint to client, from father to man, from someone who must be pleased to someone who could pleasure her" (p. 155). Her exultation derives from having defathered the father, from having seized sexual power for herself, and from having "become, at his expense, autonomous" (p. 155). Yet it is mixed with bitterness, not from guilt, of which she feels nothing, but from her recognition, as Dominic Head (2002:97) astutely observes, "that this self-assertion is a reversal of power rather than a deconstruction of the power relation itself". Her appropriation of power, moreover, is further undermined by her discovery later on that her father, knowing her identity, may well have deliberately sought her out in the first place. However the episode is interpreted, it serves as a significant redetermination of the various meanings of Praxis' name suggested earlier, the turningpoint which will eventually lead Praxis to action, though in a way which is again unexpected and transgressive. 


\subsection{The Women's Movement}

Before she reaches the moment of decisive action, however, she must pass through a further stage in the development of her consciousness as a woman. When Praxis is deserted by her second husband, Phillip, she does not feel angry: she after all had left her first husband and children in pursuit of her own happiness. But at the age of forty she no longer feels attractive to men and lacks any social purpose. Though encouraged by Irma to join the Women's Movement which she now heads, Praxis is at first reluctant, expressing her disinclination in terms which echo Weldon's earlier novel, Down among the women (1975):

A meeting of all women! She felt she would be finally relegated, down among the women. A woman past her prime, taking comfort from the company of other rejected ageing women. There was to her something infinitely depressing in the notion of any all-female group, which must lack the excitement and pleasure of mixed company. (p. 252.)

She does eventually become involved, however, drawn by the opportunity of taking over the editing of the movement's broadsheet (later newspaper), and quickly finds herself in fundamental agreement with the ideals of the movement, which had once felt alien to her but which now seemed "commonplace, and so much to her advantage that she was surprised to remember how, in the past, she had resisted them" (p. 274). Inspired by Irma's application of Kate Millett's (1970) rallying cry that the personal is political (p. 253), Praxis moves beyond merely editing the newspaper and begins writing "editorials of such power and vehemence" that she acquires a dedicated following of readers. Although she refers to them diffidently as her "diatribes", nevertheless "others found in them the stuff of revolution: the focusing of a real discontent, and with that focusing the capacity for alteration" (p. 282). She justifies whatever polemical rhetoric she employs through feeling that she is "righting some kind of balance" (p. 273), countering centuries of patriarchy with a new feminist assertiveness.

Characteristically, however, Praxis' new-found vocation as a radical feminist is presented from the outset in the narrative with a degree of ambivalence. For example, her "rousing editorials", it turns out, she only "half believed and half did not, in the same way as she had half believed, half not, her own advertisements for the Electricity Board" (p. 273). The apparent "certainty" in her writing is something "which she certainly did not find in real life" (p. 282). Even more worrying, her radical posturing begins to take on the form of "a 
religious experience", in which she feels as if she were a "convert", and with it the need to "proselytise" and make "all the women in the world think as she thought, do as she did" (p. 273-274). Soon, she begins to believe that she is the "Daughter of God" sent to "save" womankind (p. 274). Such intellectual radicalism, combined with the emotional investment of religious fundamentalism, is, of course, inherently dangerous, and Praxis is inevitably brought to see that she is "wrong" (p. 275).

Praxis' increasing loss of perspective is in fact foreshadowed earlier by her gradual acceptance of Irma's standpoint, the "whole new view of the world" (p. 265) which she has had foisted onto her. Irma's view is that "individual life is not so important" (p. 278), and that "you shouldn't invest so much in individuals ... Stick to movements: wide sweeps of existence and experience. Ignore details. It's how men get by" (p. 281-282). Not only is such grand theorising highly illiberal in its implicit rejection of the primary importance of the individual, it also betrays a disturbingly masculinist attitude, one which Praxis had noticed in Irma when she first attended a women's meeting: "Here was the new Irma, firm and strong, demanding principle, in a masculine way, denying love. For that was what it amounted to" (p. 246). Before long, Praxis begins in her editorials to reflect Irma's position, "devoting herself to the many, rather than the few" (p. 282), and though the actual content of the editorials is never made explicit in the text, it is clear that Praxis' emotions have hardened, and that, as a leading figure in the movement, she has acquired an alarmingly evangelical arrogance.

In so doing, Praxis comes to represent some of the fundamental contradictions which bedevilled radicalised second-wave feminism as it developed into the later 1970s. By adopting a militantly oppositional stance, such feminism ironically began to reflect a decidedly male perspective, utilising a masculine discourse of confrontation and force, and flaunting a female form of machismo which critics such as Ruthven (1984:9) labelled "feminist terrorism". Concomitantly, many of the best and distinctively feminine values of the movement were in danger of being lost: compassion, tolerance, humane love and a concern with the individual. And, in the quasireligious fervour ${ }^{14}$ of the movement, opinions began to become polarised and rigid, dissenting views were marginalised or excluded,

14 For an account of the profound, almost religious experience which many women found in the feminism of the 1970s, see Rowbotham (1997:398). 
and subtle debates around complex issues were replaced by selfcertain assertion as opposing strands struggled for supremacy. ${ }^{15} \mathrm{It}$ was this extremism which alienated many women (and men) from the movement, and which Praxis, in particular, has to learn is ultimately inadequate as a response to the complexity of the real world. 16

\subsection{From radical theory to liberal practice}

In the culminating episode of the novel, 17 Praxis confronts a moral dilemma which no amount of grand theorising can help her resolve. Instead, she is forced to make a decision at the level of the very individualism which she had come to reject in her editorial writing. Even more particularly, it is a decision concerning individual liberty, and in taking it she finds herself moving from a position of abstract radicalism to one of liberal practicality and humane compassion in the face of complex actuality. Her adopted daughter, Mary, who with her two small children has been left by her husband, is offered a plum position in a Toronto hospital, which, as "a hot-bed of feminism" (p. 282), is only too happy to employ a single mother. But then she falls pregnant after a one-night stand with a married man, and refuses an abortion, considering it "murder" (p. 258). Even worse, when the baby is born it turns out to be a very low-grade Down's syndrome case, and in deciding to keep it, Mary seems to have doomed herself to a life without "a future" (p. 283). Spontaneously, when Mary temporarily leaves the room, Praxis smothers the fourday old infant in an act of euthanasia, both for its sake and for Mary's. Although the doctor is prepared to believe that the baby died of natural causes, Praxis insists on accepting responsibility. Her resolve is confirmed in a key exchange with the doctor, a Pakistani

15 Rowbotham (1997:431) reports that in 1978, the year Praxis was published, a crisis of "desperate confrontation" was reached in the feminist movement when the Women's Liberation Conference "divided so acrimoniously" over certain issues "that no one was ever prepared to call another one".

16 Robbins (2000:37-40), following the work of Elaine Showalter, Cora Kaplan and others, argues that such extremism was particularly true of Marxist feminism, and, further, that the merging of feminism with Marxism led invariably to "a very unequal marriage", which was to the detriment of feminism.

17 As Olga Kenyon (1988:117) has revealed, "the final pages are speeded up, as Weldon completed them in two weeks in hospital, waiting for her fourth child, afraid of possible death from a misplaced placenta". It is necessary to take this compression into account, therefore, and to realise that the relatively brief climax and denouement nevertheless carry a great deal of significance. 
woman who has worked in war-torn Bangladeshi famine areas and has seen thousands die. In one simple sentence, the doctor refutes Praxis' current stock denial of the importance of the individual and her reluctance to engage with reality:

'We can't think about individuals all the time', said Praxis.

'I do', said Dr. Gibb. (p. 288.)

Praxis is then arrested, but receives instead of life-time imprisonment a relatively lenient two-year sentence. Even this is complicated in the novel by the fact that the patriarchal judge bases his verdict on how the new abortion laws in England had confused both the moral and legal issues,18 and how in Ancient Rome "the father exercised the right of life and death over a new-born baby", especially if it was "defective" (p. 290).

Weldon does not pass judgement explicitly in the narrative on Praxis' actions, but allows the full complexity of the issue to present itself in the text. In the light of the reformed abortion laws, for example, Praxis argues that killing a four-day-old imperfect baby is not worse than killing a four-month-old perfect foetus (p. 290), but she nevertheless suffers from an overwhelming sense of guilt and horror at what she has done. Public opinion, as expressed by her fellow prisoners, the media and the crowds who flock to her trial, is similarly divided. There are as many who revile her as a murderer as there are those who celebrate her as a champion of women's rights. For her own part, she does not care what people think; she knows that she acted out of practical necessity and compassion for Mary, and in opposition to a reductive and naïve view of what is natural, especially for women: as she observed in an earlier section of the novel, "Nature does not know best, or if it does, it is on the man's side" (p. 158). What she has now done, therefore, was "the rectifying of a mistake ... Nature's error, not God's purpose" (p. 284). As such, it is clear that Praxis construes her decision not only as an act of female solidarity, but also, from a distinctively liberal perspective, as an assertion of the right to liberty of individual women. As Weldon (in Kenyon, 1988:114) explained in a public discussion of her work, "Praxis wanted to liberate her step-daughter [sic] Mary, who otherbut abortion on demand was still a highly contentious issue throughout the 1970s. 
wise would be put into a lifetime's servitude by her loving female nature".

In choosing this course of action, Praxis feels, at the broadest level, that she has finally come to terms with the destiny which she has always sensed was meant for her. 19 Throughout the novel, she has postulated that

... there was some force guiding the affairs of the universe, working its way peacefully through the chaos of human societies, towards an end of its own devising, and that she had some part to play in it, however humble (p. 138).

The older Praxis learns that this process is not always so peaceful, that perhaps "we are in the grip of some evolutionary force which hurts as it works" (p. 16), but that nevertheless it is "a force which turns the wheels of action and reaction, and gives meaning and purpose to our lives" (p. 295). And now that she has been brought to the point of action, she can be consoled, even in her darkest moments, by "the visionary notion that the act of killing had not been petty, sordid, ordinary and mad, but that she had been the instrument of some higher will" (p. 287).

On a more personal level, for Praxis the episode provides a practical clarification of the significance of her name, a turning-point or culmination, where her diffuse theories of life reach the moment of decisive action (p. 11).20 Earlier she had begun to realise that happiness is not to be found in any particular person or thing, that the various experiences of human life are "part of the journey" and "not the end of the journey" (p. 249). A little later, just before her momentous act, she confirms this revelation:

Human lives travel through time like the waves of the sea, rising to peaks of experience, falling again, gathering new strength, to rise once more. There is no finite point at which we can say, ah, I have arrived: I am saved: I am rich, successful, happy. (p. 275.)

19 This destiny is symbolised for Praxis by the star Betelgeuse. Weldon has had a life-long fascination with astrology, but her astronomical knowledge evidently lags somewhat behind, as she repeatedly labels Betelgeuse a red dwarf star when it is in fact a red supergiant.

20 One "meaning" of Praxis' name is never made entirely clear in the novel. The "Goddess" (p. 11) whose name most closely approximates hers is "Praxidike", but the etymology of this name is rather different, and she is associated with "exacting justice", which is hardly what best describes Praxis in the novel. 
Through her action, she is able to move beyond mere theorising, beyond the rhetoric of her editorial diatribes which were always somehow disconnected from "real life" (p. 282), and she is capable at last of participating fully in a world of actual, valid individual experience:

... for once Praxis was not unsure as to what was reality and what was not. What she remembered and what had happened were identical. She had passed into the real world, where feelings were sharp and clear, however painful. (p. 286.)

And finally, at the very end of the novel, she can claim to have reached a point where her personal issues merge with those of others, where the particular concerns of women are seen in the context of humanity in general, and where she is able to engage with other people in a truly meaningful way: "The wall which surrounded me is quite broken down. I can touch, feel, see my fellow human beings." (p. 295.)

\section{Conclusion}

The critic, Jenny Newman (1993:189), once famously described Fay Weldon's fiction as "survival manuals for women". It would be a mistake, however, to regard Weldon as merely providing an unambiguous programme of action for women to follow. Rather, if there is a practical dimension to her work, then it is to be found in the force with which she presents complex, challenging ideas, and the skill with which she compels demanding, often unsettling debates. This is especially true of a novel like Praxis, in which a number of issues concerning the evolving identities and roles of women in a rapidly changing society are explored with rare candour and insight. As Dominic Head (2002:97) points out, "it is not so much the actual events described that form the challenge, as the realisation that positive feminist action depends on a difficult and subversive overturning of accepted social codes". He goes on to note that "a seminal aspect of [Weldon's work] is the resistance of easy or obvious positions" and that she "is especially wary of the unthinking or fanatical stance". For many critics, this has made Weldon a problematic figure in the feminist movement. From a liberal point of view, however, the very openness and pluralism of the ideas which she explores may be seen as a strength rather than a limitation.

In particular, as this article has attempted to demonstrate, Praxis may be regarded as a prescient anticipation of what has proved to be the most fruitful line of development for feminism beyond the 
second-wave, as the main character moves from being a subservient woman complicit in patriarchy, to a combative leader of a radical women's movement, to someone who is able to move beyond a restricting conception of gender to engage on a deeply personal level with her "fellow human beings" (p. 295). In this, the novel looks forward to the general shift in feminist thought since the 1980 s towards a more inclusive humanist orientation in which gender issues and the rights of women are subsumed under an expanded conceptualisation of human rights. It even predates Betty Friedan's (1981:343) call for "human liberation" rather than merely "women's liberation":

If we can eliminate the false polarities and appreciate the limits and true potential of women's power, we will be able to join with men - follow or lead - in the new human politics that must emerge beyond reaction.

As the feminist scholar Rosalind Coward (1999:219) has more recently suggested, it is debatable whether or not feminists in the new millennium "want to continue special pleading for women's interests or defending women's rights as greater or more pressing than men's ... Would it not be more helpful to be looking at human rights and at the rights of all members of society?"

This is not to imply, of course, that patriarchy has been totally dismantled in any contemporary society, or that there are not specifically female issues to be addressed, and therefore the vogue phrase "post-feminism" seems premature and misleading (see, for example, Coppock et al., 2005).21 But it is important to acknowledge that the substantial accomplishments in breaking down patriarchal power structures and achieving greater gender equality in society have been specifically liberal and humanist in nature. As Ruth Robbins (2000:25) puts it,

... the significant successes of feminist activism have been in the realm of extending individualism to include women. In particular, the opening up of higher education and the professions to bourgeois women at the end of the nineteenth century, the extension of the franchise to women in the early years of the twentieth century, and the more recent institution of equal rights

21 Other feminist commentators have argued that a "third-wave feminism" has emerged in recent years, though the nature and significance of this form of feminism remains highly contested (see the differing views of Shalit (2007) and Siegel (2007), for example). 
legislation, maternity rights, the availability of safe and reliable contraception, have been successes of feminism in its liberal guises. There are on-going battles to achieve affordable childcare for working parents, and to undo the prejudice that still prevents some women from reaching the heights of their professions. These legislative and cultural changes are the logical correlative of a philosophical position that divorces sex from gender, and that insists that biology need not be destiny. The changes are very significant and have made real differences to real people's lives.

It is in the light of such successes, achieved through rational reform rather than oppositional extremism, that feminist political philosophers such as Karen Green (1995:9), looking to the future, have been able to argue that "the best prospect for developing a coherent vision of a non-patriarchal society lies in the development of a feminist humanist tradition", or as Janet Todd (1991:135) poignantly asserts:

... however battered, deconstructed, and scorned, the enlightenment's individualistic liberalism, its belief in rational advance and its aim of increasing freedom and equality through greater awareness of self and culture still form the ground of hope and of collective action.

It is this belief that the world can be changed, and that the lives of women in particular can be made better, that forms the core of Fay Weldon's novelistic vision. In this, the view of Weldon and her character, Praxis, seem to merge, as Praxis comes to understand that "you learn to love the world enough to want to change it" (p. 277). Weldon clearly endorses the vision which Praxis achieves of the wide diversity of women who are nonetheless united in their growing awareness that "the capacity for alteration" (p. 282) lies in their hands:

Those whom she had previously regarded as rejected, humiliated, obsessive, angry and ridiculous, she began to see as brave, noble, and attempting, at any rate, to live their lives by principle rather than by convenience. All kinds of women young and old, clever, slow, pretty, plain, the halt and the lame, the sexually confused, or fulfilled, or indifferent, battered wives, raped girls, vicious virgins, underpaid shop assistants, frustrated captains of industry, violent schoolgirls, women exploited and exploiting - all turning away from their inner preoccupations and wretchedness, to regard the outside world and see that it could be changed. (p. 277.) 
If one of the characters in Praxis is even partially correct in asserting that "fiction does more to change the world than any amount of fact" (p. 239), then Fay Weldon, in writing novels that not only reflect the complex issues facing women in society but that also point the way to ever greater emancipation, can claim with some justification, like Praxis herself, "I changed the world a little" (p. 58).

\section{List of references}

BARRECA, REGINA, ed. 1994. Fay Weldon's wicked fictions. Albany: University of New England.

BLAMIRES, HARRY. 1983. A guide to twentieth century literature in English. London: Methuen.

BYATT, A.S. 1979. A.S. Byatt on the Booker shortlist. The Literary Review, 1011, Nov.

CLARK, ALEX. 2002. Life and loves of an optimist. The Guardian: 1-2, 18 May. http://books.guardian.co.uk/print/0,3858,4415474-99942,00.html Date of access: 23 May 2007.

COPPOCK, VICKI, HAYDEN, DEENA \& RICHTER, INGRID. 2005. The illusion of "post-feminism": new women, old myths. London: Taylor \& Francis.

COWARD, ROSALIND. 1999. Sacred cows: is feminism relevant in the new millennium? London: HarperCollins.

FRENCH, MARILYN. 1978. Publicity quotation. (In Weldon, Fay. Praxis. London: Sceptre.)

FRIEDAN, BETTY. 1981. The second stage. London: Abacus.

FRIEDMAN, MARILYN. 2003. Autonomy, gender and politics. Oxford: Oxford University Press.

GREEN, KAREN. 1995. The woman of reason: feminism, humanism and political thought. Oxford: Polity Press.

HEAD, DOMINIC. 2002. The Cambridge introduction to modern British fiction, 1950-2000. Cambridge: Cambridge University Press.

IRIGARAY, LUCE. 1985. This sex which is not one. Transl. by Catherine Porter with Carolyn Burke. Ithaca: Cornell University Press.

JEFFRIES, STUART. 2006. Lie back and think of Jesus. The Guardian: 10, 5 Sept.

KENYON, OLGA. 1988. Women novelists today: a survey of English writing in the seventies and eighties. Brighton: Harvester.

KENYON, OLGA, ed. 1989. Women writers talk: interviews with 10 women writers. New York: Carroll \& Graf.

KUMAR, MINA. 1995. Interview with Fay Weldon. Belles lettres, 10(2):16-18.

LOWRY, SUZANNE. 1982. Interview with Fay Weldon. Sunday Times: 25, 24 Sept.

MILL, JOHN STUART. 1906 [1869]. The subjection of women. London: Longmans.

MILLETT, KATE. 1970. Sexual politics. London: Sphere.

MOI, TORIL. 1985. Sexual/textual politics. London: Methuen.

NEWMAN, JENNY. 1993. "See me as Sisyphus, but having a good time": the fiction of Fay Weldon. (In Hosmer, Robert E., ed. Contemporary British women writers. Basingstoke: Macmillan. p. 188-211.)

NOZICK, ROBERT. 1974. Anarchy, state and utopia. Oxford: Blackwell. 
NUSSBAUM, MARTHA C. 2006. Frontiers of justice. Cambridge: Harvard University Press.

OKIN, SUSAN MOLLER. 1989. Justice, gender and the family. New York: Basic Books.

O'NEILL, ONORA. 2000. Bounds of justice. Cambridge: Cambridge University Press.

PALMER, PAULINA. 1990. Contemporary lesbian feminist fiction. (In Anderson, Linda, ed. Plotting change: contemporary women's fiction. London: Arnold. p. 43-64.)

ROBBINS, RUTH. 2000. Literary feminisms. Basingstoke: Macmillan.

ROWBOTHAM, SHEILA. 1997. A century of women: the history of women in Britain and the United States. Harmondsworth: Penguin.

RUBENSTEIN, ROBERTA. 2005. The feminist novel in the wake of Virginia Woolf. (In Shaffer, Brian W., ed. A companion to the British and Irish novel 1945-2000. Oxford: Blackwell. p. 45-64.)

RUTHVEN, K.K. 1984. Feminist literary studies: an introduction. Cambridge: Cambridge University Press.

SAGE, LORNA. 1992. Women in the house of fiction: post-war women novelists. Basingstoke: Macmillan.

SAPIRO, VIRGINIA. 1992. A vindication of political virtue: the political theory of Mary Wollstonecraft. Chicago: University of Chicago Press.

SHALIT, WENDY. 2007. Girls gone mild: young women reclaim self-respect and find it's not bad to be good. Toronto: Random House.

SIEGEL, DEBORAH. 2007. Sisterhood interrupted: from radical women to grrls gone wild. New York: Macmillan.

STEVENSON, RANDALL. 1993. The twentieth-century novel in Britain. New York: Wheatsheaf.

TODD, JANET. 1991. Feminist literary history. Cambridge: Polity Press.

WELDON, FAY. 1967. The fat woman's joke. London: MacGibbon \& Kee.

WELDON, FAY. 1971. Down among the women. London: Heinemann.

WELDON, FAY. 1974. Female friends. London: Heinemann.

WELDON, FAY. 1978. Praxis. London: Sceptre.

WELDON, FAY. 1982. The life and loves of a she-devil. London: Coronet.

WELDON, FAY. 1997. Big women. London: Flamingo.

WELDON, FAY. 1998. Preface to Jill Neville, the love germ (1969). London: Verso.

WELDON, FAY. 2001. The Bulgari connection. London: Flamingo.

WELDON, FAY. 2002. Auto da Fay. London: Flamingo.

WELDON, FAY. 2006. What makes women happy. London: HarperCollins.

WELDON, FAY. 2007. The spa decameron. London: Quercus.

YOUNG, IRIS MARION. 1990. Justice and the politics of difference. Princeton:

Princeton University Press. 


\section{Key concepts:}

Fay Weldon

feminism

fiction

liberalism

Weldon, Fay: Praxis

\section{Kernbegrippe:}

Fay Weldon

feminisme

liberalisme

romankuns

Weldon, Fay: Praxis 